\title{
Infected Subcutaneous Hematoma and Pneumomediastinum in a Patient with Chronic Liver Disease
}

\author{
Kronik Karaciğger Hastalığı Olan Olguda Cilt altı Enfekte Hematom ve \\ Pnömomediastinum
}

Mehmet Ali Aslaner, Mehmet Ali Karaca

Department of Emergency Medicine, Hacettepe University Faculty of Medicine, Ankara, Turkey

\begin{abstract}
Introduction: Morbidity and mortality are significantly associated with bacterial infection in cirrhotic patients. Immune system mechanisms tend to be abnormal in patients with chronic liver disease. The causes of mortality in cirrhotic patients are associated with bacterial infections by $25 \%$. Also, another problem with chronic liver disease is disorders in hemostasis. Although coagulopathy is mostly seen in acute liver failure, the most serious complication of liver cirrhosis and chronic liver failure is coagulopathy disorders.
\end{abstract}

Case Report: A 61-year-old man with chronic liver disease was admitted to the emergency department with swelling in his left shoulder. In his history, after falling in the bathroom, a hematoma in the left scapular region developed; then, the hematoma became spontaneously infected.

Conclusion: Even minor trauma can cause bleeding in patients with abnormal hemostasis parameters. These body fluids can become infected in the presence of underlying disease. Skin infections, particularly abscesses and collections, require drainage; sampling should be made; and appropriate antibiotic therapy must be initiated as soon as possible.

Keywords: Chronic liver disease, infected hematoma, pneumomediastinum, emergency

Received: 10.07.2013 Accepted: 03.12.2013

\section{ÖZET}

Giriş: Sirotik hastalarda bakteriyel enfeksiyon, morbidite ve mortalitenin en önemli nedenlerindendir. Kronik karaciğer hastalarında immünsistem mekanizmaları bozulmuştur. Sirotik hastalarda mortalite nedenlerinin \%25'i bakteriyel enfeksiyon olduğu kabul edilir. Kronik karaciğer hastalığında diğer bir sorun hemostaz bozukluklarıdır. Ağır koagülopati akut karaciğer yetmezliğinde sık olarak görülse de, karaciğer sirozu ve kronik karaciğer yetmezliğinin en ciddi komplikasyonudur.

Olgu Sunumu: Banyoda düşme sonrası sol skapula üzerinde hematom gelişen ve sonrasında spontan enfekte hematoma ilerleyen, 61 yaşındaki erkek, kronik karaciğer hastası anlatılacaktır.

Sonuç: Küçük travmalar, kanama parametreleri anormal olan hastada kanamalara neden olabilir. Altta yatan hastalık varlığında vücut sıvıları enfekte hale gelebilir. Cilt enfeksiyonlarında, özellikle apse ve koleksiyonlarda drenaj gereklidir. Bu koleksiyonlardan örnekleme yapılmalı ve en erken zamanda uygun antibiyotik tedavisi başlanmalıdır.

Anahtar Kelimeler: Kronik karaciğer hastalığı, enfekte hematom, pnömomediastinum, acil

Geliş Tarihi: 10.07.2013 Kabul Tarihi: 03.12.2013

\section{Giriş}

Bakteriyel enfeksiyonlar akut karaciğer hastalıklarından ziyade, kronik yetmezliklerde daha sık görülmektedir. Sirotik hastalarda etkenlerin yarısının toplum kökenli, daha az kısmında ise hastane kökenli olduğu bulunmuştur. Esas etken gram (-) bakteriler olduğu gösterilmişse de gram (+) etkenler de yer almaktadır. Bakteriyel enfeksiyonlarda, humoral ve hücresel savunma 
mekanizmaları ile retikuloendotelyal sistem mekanizmaları rol oynamaktadır. Karaciğer fonksiyon bozukluğunda, enfeksiyona karşı humoral ve hücresel konak savunması daha sık bozulmaktadır fakat defektif retiküloendotelyal fagositik fonksiyon daha fazla enfeksiyon riski ve kötü prognoza sahiptir (1).

Hemostazda ise karaciğer merkezi bir rol oynar. Kronik karaciğer hastalığında; faktör V, VII, IX, X, XI, protrombin ve fibrinojen sentezinde azalma vardır. A2-plazmin inhibitörü sentezindeki yetersizlik fibrinolize neden olur. Bozulmuş hemostatik mekanizmanın devamında da dissemine intravasküler koagulasyon (DIC), disfibrinojenemi, hipersplenizmin sebep olduğu trombositopeni gelişir.

Kan koagulasyon proteinlerindeyetersizlik ve enfeksiyon, koagülopati ve kanama riskinde artmaya neden olur (2). Aynı zamanda sirotik ya da alkolik karaciğer hastalığında enfeksiyona yatkınlık ise daha fazladır (1). Bu kısır döngü akut karaciğer yetmezliğinde daha azdır.

Kronik karaciğer hastalığı olan ve travmaya bağlı cilt altı enfekte hematomu olan olguyu sunuyoruz.

\section{Olgu Sunumu}

Kronikalkol kullanımına bağlı karaciğer hastalığı olan 61 yaşında erkek hasta, 10 gün önce sırtını duvara çarpma sonucu skapula bölgesinde küçük bir şişlik meydana gelmesi sonrası şişliğin tüm sol skapula bölgesi üzerinde yayılması ile acil servise başvuruyor. Hastanın 30 yıldır alkol alım öyküsü ve daha öncesinde de hepatik ensefalopati nedeni ile yatış öyküsü bulunmaktaydı. Hastanın fizik muayenesinde

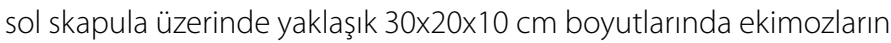
eşlik ettiği cilt altı şişliği mevcuttu. Vital bulguları normal sınırlarda saptandı. Hastanın bakılan tetkiklerinde INR: 3,18 (0,86-1,26) , APPT: 48,7 sn (27-38), WBC: $26 \times 10 \wedge 3 / \mu \mathrm{L}(4,3-10,3)$ ve PLT: $84 \times 10 \wedge 3 / \mu \mathrm{L}(150$ 370) olarak görüldü. Akciğer grafisinde seviyelenme veren serbest sıvı görünümü (Resim 1) plevral effüzyon ile uyumlu olmaması üzerine yapılan USG sonucu "cilt altı enfekte hematom" olarak rapor edildi. Eritrosit süspansiyonu, vital bulguları ve hemoglobin değerlerinin stabil olması nedeniyle gerek görülmedi. Hastaya PTZ-INR yüksekliği nedeniyle Taze Donmuş Plazma (TDP) verildi fakat istenilen kan koagülasyon düzeyine erişilemediği için örnekleme yapılamadı. Vitamin K, kronik karaciğer hastalığında etkisi kesin olmaması, faktör kompleksi ise hazırda mevcut bulunamaması nedeniyle verilemedi. Enfeksiyon Hastalıkları bölümü ile konsülte edilerek sülbaktamampisilin başlandı. Yapılan Toraks BT'de"yaygın pnömomediastinum, paraspinal alan, sırt posterioru ve posterolateralini etkileyen en kalın yerinde $6,5 \mathrm{~cm}$ kalınlığa ulaşan içinde hava da izlenen kolleksiyon (enfekte hematom?, apse?). Göğüs duvarında, supraklaviküler bölgede bilateral yaygın amfizeme bağlı hava görünümleri" olarak raporlandı (Resim 2, 3). Hastanın pnömomediastinumu travmaya sekonder alveolar rüptürüne bağlandı.

Takipte bilinç değişikliği gelişmesi üzerine yapılan Kranial BT normal sınırlarda olarak rapor edildi ve bilinç bulanıklığı hepatik ensefalopatiye bağlanarak, İ̧ Hastalıkları bölümü ile konsulte

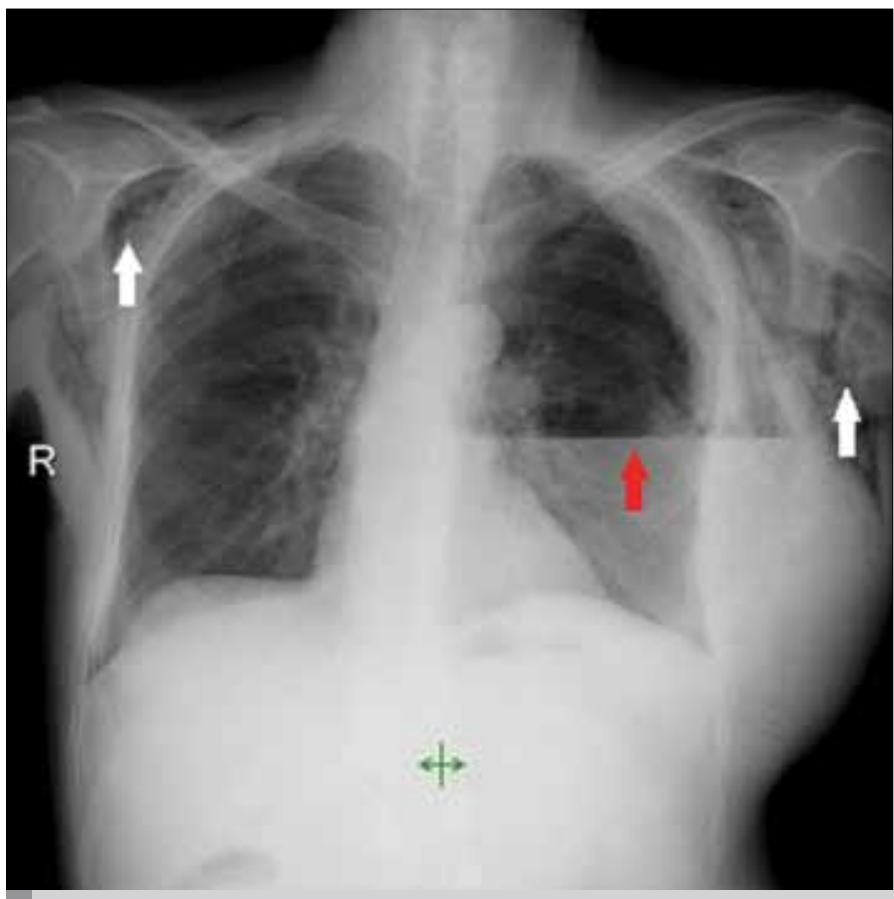

Resim 1. Mediasten sol kesimde seviyelenme veren cilt altı serbest sıvı görünümü (kırmızı ok) ve cilt altı yaygın amfizem (beyaz ok)

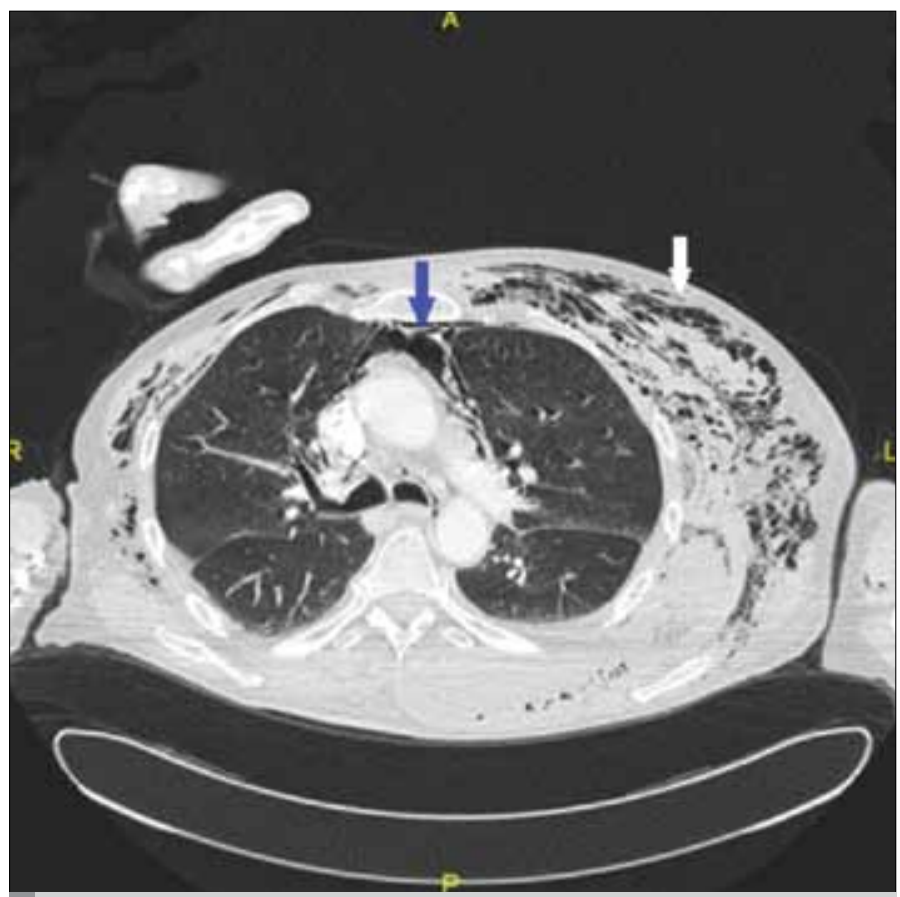

Resim 2. Pnömomediastinum (mavi ok) ve yaygın cilt altı amfizemi (beyaz ok)

edilerek kronik alkolik karaciğere bağlı hepatik ensafalopati tedavisi başlandı. Acil serviste izleminin 4. gününde iç̧ Hastalıkları Yoğun Bakım ünitesine devir edilen hastaya PTZ-INR yüksekliği ve platelet düşüklüğü açısından TDP ve trombosit süspansiyonu verilmesi ardından Girişimsel Radyoloji bölümü tarafından hastaya perkütan apse drenajı yapıldı ve dren takıldı. Apse drenajı yayma sonucunda Gram-pozitif kok gelmesi üzerine tedaviye vankomisin eklendi. 


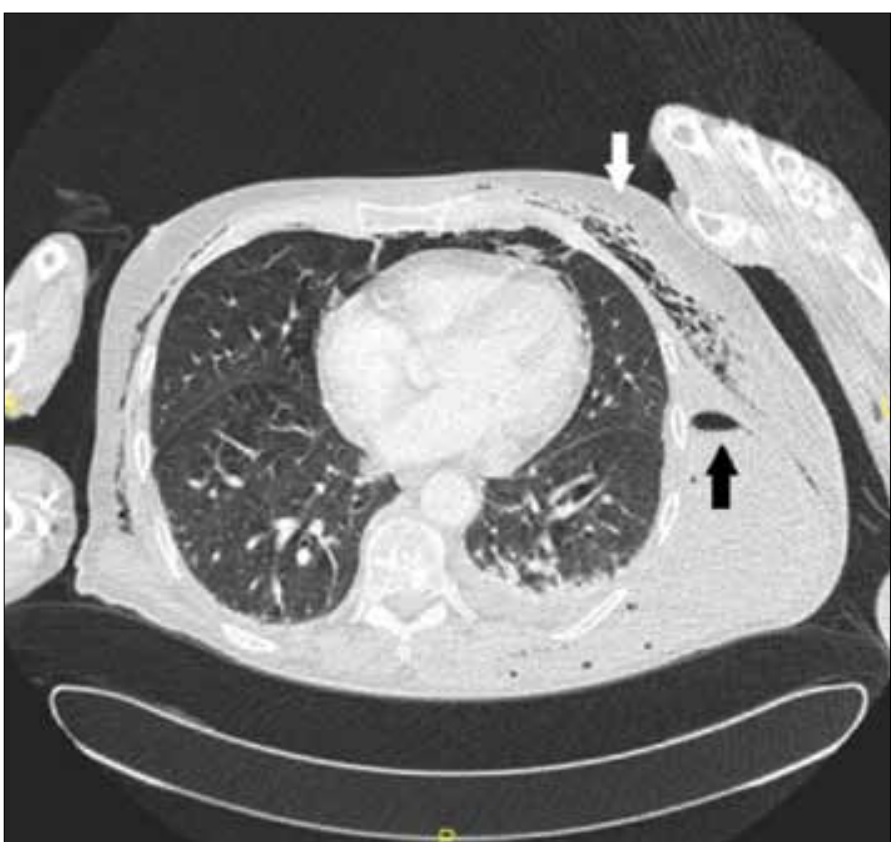

Resim 3. Yaygın cilt altı amfizemi (beyaz ok) ve bu kesitte daha belirgin seviyelenme veren cilt altı serbest sıvı görünümü (siyah ok)

Gönderilen kan amonyak düzeyi normal sınırlarda geldi. Takipte hastanın bilinci kapalı seyretti, ağılı uyaranlara yanıt veriyordu. Hastanın ağzındaki nekrotik krutlu yara bölgesinden yapılan örneklemesinde mukormukoz düşünülerek amfoterisin-b başlandı. Takipte saturasyonları düşen hasta entübe edildi. Hastaneye yatışının sekizinci gününde ise exitus oldu.

\section{Tartışma}

Bakteriyel enfeksiyonlar sirotik hastalarda önemli bir mortalite ve morbidite sebebidir (3). Akut karaciğer yetmezliğinden ziyade alkolik ve sirotik hastalarda, retiküloendotelyal fagositik fonksiyonda azalma hastalığın patogenezinde gösterilen önemli bir mekanizmadır. Kronik karaciğer hastalarında korkulan ve mortaliteyi belirleyen etkenler, kanamalar (gastrointestinal) ve bakteriyel enfeksiyonlardır. Bakteriyel enfeksiyonlar mortalite ve morbidite de iki kat risk taşımaktadır. Bu nedenle sirotik hastalarda kanama riski ve enfeksiyonun varlığı hızlı belirlenmelidir (4). Bakteriyel enfeksiyon geliştiğinde ensefalopati, böbrek yetmezliği ve şok mortaliteyi arttırmaktadır (5).

Sirotik hastaların \%32-34 ünde başvuru esnasında ya da sonraki dönemde hastaneye yatış periyotları sırasında bakteriyel enfeksiyon geliştiği görülmüştür (6). Enfeksiyonu olan sirotik hastaların hastane içi mortalite oranları \%15 civarındadır. Bu oran enfeksiyonu olmayan sirotik hastaların mortalite oranlarının iki katıdır (7).

Kronik karaciğer hastalığı, kazanılmış immün yetmezliğin en sık sebeplerinden biridir. Septik immünsuprese hastalarda, erken antibiyoterapinin olumlu sonuçları birçok çalışmada gösterilmiştir (8). Bu hasta grubunda semptomlar olmasa bile erken dönemde enfeksiyon açısından dikkatli olunmalıdır. Erken tanı, etkin antibiyotik kullanımı ve destek tedavisi sirotik hastalarda morbidite ve mortaliteyi düşürmektedir (4). Antibiyoterapinin uygunsuz kullanımı ise antibiyotik direncine sebep olmakta ve ileri dönemlerde yıkıcı sonuçlara neden olabilmektedir.

Sirotik hastalarda en sık görülen enfeksiyonlar; toplum kökenli olup sırası ile spontan bakteriyel peritonit (\%25), üriner sistem enfeksiyonu (\%20), solunum yolu enfeksiyonları (\%15), dermatolojik enfeksiyonlar(\%10) ve bakteriyemidir (\%12). Bakteriyemi; spontan yada cilt, akciğer, mesane gibi spesifik bölgelerin enfeksiyonuna sekonder gelişebilir. Riski en fazla arttıran durumlar ise hastanede yattığı dönemde hastaya uygulanan invaziv girişimlerdir (9).

Enfeksiyon odağı açısından, cilt dokusu kronik karaciğer hastalığında diğer bölgelere göre daha az sıklıkta görülür. 200 siroz hastası ile yapılan bir çalışmada cilt enfeksiyonu oranları ve risk faktörleri araştırılmıştır. Hasta grubundaki cilt kaynaklı enfeksiyon oranı \%10 ve mortalite oranı \%19 bulunmuştur. Risk faktörü olarak ise enfekte hastaların 3/4'ünde açık alanda yalın ayak ile gezme öyküsü saptanmıştır. Enfekte hastaların izleminde hemorojik büllü selülit, bacak ülseri, enfekte nasır ve abse görülmüştür (10).

Bizim hastamız geç dönemde acil servise başvursa da antibiyoterapisi en kısa sürede başlandı. Enfeksiyon odağından örnekleme yapma süreci koagülasyon parametrelerinin uygun olmaması nedeniyle ertelendi. Antibiyoterapi başlanmasına ve pozitif kültür sonuçlarına göre spektrum değiştirilmesine rağmen hastada sepsis ve buna bağlı olarak da multiorgan yetmezliği gelişti. Kronik karaciğer hastalığı olan hastalarda klinik şüphe var ise erken dönemde enfeksiyon odağı taramaları yapmak gereklidir. En kısa sürede dokudaki enfeksiyon odağı boşaltılmalı, örnekleme yapılmalı, antibiyotik tedavisi başlanmalı ve yayma ve kültür sonucuna göre antibiyoterapi yeniden gözden geçirilmelidir. Klinik düzelme göstermeyen hastalarda enfeksiyon odakları tekrar taranmalıdır.

Dışarıdan girişim olmadığı halde hastamızda, travma sonrası kan koagülasyon parametrelerindeki bozukluk nedenli cilt altı hematom gelişmiş sonrasında ise hematom, enfekte olup hastada bakteriyemiye neden olmuştur. Sirotik hastalarda, travma sonucu gelişen hematomun enfekte olup hastada bakteriyemi geliştirmesi nadir görülen ama dikkat edilmesi gereken bir durumdur.

\section{Sonuç}

Kronik karaciğer hastalığı hem hemostaz parametrelerini etkileyen hem de enfeksiyona yatkınlığa neden olan tedavisi uzun ve meşakkatli bir durumdur. Bu tür hastalar dikkatle değerlendirilmeli, basit sağlık problemleri için gerekli önlemler erken dönemde alınmalıdır. İleri tetkikler için şüphe sınırı düşük tutulmalı ve antibiyoterapi mümkün olan en erken sürede başlanmalıdır.

Informed consent: Informed consent was not received by the patient.

Peer review: Externally peer-reviewed.

Author contributions: Concept - M.A.A.; Design - M.A.A.; Supervision - M.A.K.; Data Collection and/or Processing - M.A.A.,M.A.K.; Analysis 
and/or Interpretation - M.A.A.,M.A.K.; Literature Review - M.A.A.; Writer - M.A.A.; Critical Review - M.A.K.

Conflict of interest: The authors declared no conflict of interest.

Financial Disclosure: The authors declared that this study has received no financial support.

Hasta Onamı: Hasta kimlik bilgileri gizli tutulduğundan ve iletişim bilgileri bulunamadığından hasta onamı alınmadı.

Hakem değerlendirmesi: Dış bağımsız.

Yazar Katkıları: Fikir - M.A.A.;Tasarım - M.A.A.; Denetleme - M.A.K.; Veri toplanması ve/veya işlemesi - M.A.A.,M.A.K.; Analiz ve/veya yorum M.A.A.,M.A.K.; Literatür taraması - M.A.A.; Yazıyı yazan - M.A.A.; Eleştirel inceleme - M.A.K.

Çıkar Çatışması: Yazarlar herhangi bir çıkar çatışması bildirmemişlerdir. Finansal Destek: Yazarlar bu çalışma için finansal destek almadıklarını beyan etmişlerdir.

\section{Kaynaklar}

1. Wyke RJ. Problems of bacterial infection in patients with liver disease. Gut 1987; 28: 623-41. [CrossRef]
2. Pluta A, Gutkowski K, Hartleb M. Coagulopathy in liver diseases. Adv Med Sci 2010; 55: 16-21. [CrossRef]

3. Christou L, Pappas G, Falagas ME. Bacterial infection-related morbidity and mortality in cirrhosis. Am J Gastroenterol 2007; 102: 1510-7. [CrossRef]

4. Bernard B, Cadranel JF, Valla D, Escolano S, Jarlier V, Opolon P. Prognostic significance of bacterial infection in bleeding cirrhotic patients: a prospective study. Gastroenterology 1995; 108: 1828-34. [CrossRef]

5. Taneja SK, Dhiman RK. Prevention and management of bacterial infections in cirrhosis. Int J Hepatol 2011; 2011: 784540.

6. Borzio M, Salerno F, Piantoni L, Cazzaniga M, Angeli P, Bissoli F ve ark. Bacterial infection in patients with advanced cirrhosis: a multicentre prospective study. Digestive and Liver Disease. vol. 33, no. 1, pp. 41-48, 2001. [CrossRef]

7. Wong F, Bernardi M, Balk R, Christman B, Moreau R, Garcia-Tsao G ve ark. Sepsis in cirrhosis: report on the 7th meeting of the International Ascites Club, Gut, vol. 54, no. 5, pp. 718-725, 2005. [CrossRef]

8. Runyon BA. Bacterial infections in patients with cirrhosis. J Hepatol 1993; 18: 271-2. [CrossRef]

9. Fernandez J, Navasa M, Gomez J, Colmenero J, Vila J, Arroyo V ve ark. Bacterial infections in cirrhosis: epidemiological changes with invasive procedures and norfloxacin prophylaxis. Hepatology 2002; 35: 140-8. [CrossRef]

10. Mohan P, Ramu B, Bhaskar E, Venkataraman J. Prevalence and risk factors for bacterial skin infection and mortality in cirrhosis. Ann Hepatol 2011; 10: 15-20. 